The Third Pole: Journal of Geography

Vol. 20 - 21: 83-100, 2021

DOI: https://doi.org/10.3126/ttp.v21i01.41620

Department of Geography Education,

Central Department of Education, T.U., Kathmandu, Nepal

\title{
IMPLICATIONS OF KEY PHILOSOPHICAL ASSUMPTIONS AND PARADIGMS IN GEOGRAPHY TEACHING AND RESEARCH
}

\section{Abstract}

\section{Kanhaiya Sapkota ${ }^{1}$ Narayan Prasad Paudyal}

Geography has had limited interchange with the implications of major philosophical assumptions and paradigms in geographical education and research methodology. This paper claims a closer engagement with the philosophical arguments on ontology, epistemology, and axiology as well as the research and teaching strategies or paradigms. It is adopted and has much to offer to geography, not least in providing a showground within which very different types of geographical inquiry i.e., qualitative and quantitative, may find some common ground for helpful discussion and debate in geographic research. Nevertheless, this will only be fully accomplished if geography enters on: (1) studies that develop and arrange clear positivist ideas and concepts within the particular geographic research; (2) studies that attempt to relate geographic research to the broader realm of the constructionism/ interpretivism tradition; and (3) examination of the link of the geographic research with the pragmatism. The contemporary revival of geographic paradigm is described, together with its impacts on research and teaching methodology in geography. The prevailing literature on geographical rendezvous with positivism is then examined, and it is claimed that there is a single reality, which can be measured and known. Therefore, they are more likely to use quantitative methods to measure the fact. Likewise, constructivist believe that there is no single reality or truth. Thus, existence need to be interoperated, and consequently they are more likely to use qualitative methods to get those multiple realities. Pragmatism has much broader relevance within both physical and human geography, not linked to particular research styles. It believes that truth or reality is constantly negotiated, debated, interpreted and therefore, the best method to use is to solve the problem or explores the truth or fact.

Keywords: Ontology, epistemology, axiology, metaphysics, philosophical assumption, pragmatism, positivism, constructivism.

1 Dr. Sapkota is a Associate Professor, Central Department of Geography Education, T.U. email: kanhaiya.sapkota@cdg.tu.edu.np.,

2. Dr. Paudyal is a Professor, Central Department of Geography Education, T.U. email:Paudyal_narayan@yahoo.com 


\section{Introduction}

In the past, there had been very a limited interactions and discussions on the implications of major philosophical assumptions and paradigms in geographical education and its research methodology (Cohen, Manion, and Morrison, 2006). However, currently, geography is characterized by a great deal of lively debate, which focuses not so much on its subject matter as on its philosophy, but its orientation to its subject matter as well (Johnston, 1984; 1986). Much more than was so in the 70's decade, geographers are being exposed to debate within philosophy, as they refer to the natural and the social sciences (Couper, 2015). The foundation of the geographical study is excavated with the relevant and genuine questions always expected to address by the geographers. For instance, what are the goals of geographic research? How can these be achieved? And so on.

The philosophical autopsy always raised in geographic research. What is the nature of philosophy? It is not an easy task to define academically. However, it is pretty interesting to define by two significant ways, either by pointing towards specific "objects" or "methods" (Suchet-Pearson, Wright, Lloyd and Burarrwanga, 2013). Regarding the concept of "objects" which is about what is the discipline is about, and the "methods" deals with about how we do or conduct research in our domain or how do we do philosophy and how do we philosophies them. Thus, what is the object of philosophy, or what is the philosophy? Now it's not immediately clear what philosophy is about because philosophy does not have a similar conspicuous object. The term "philosophy" is derived from Greek, where "philo" means love and "sophy" means knowledge or understanding. Thus, it is known as the love of wisdom or friendship of wisdom. Again, it does not reflect the explicit meaning of philosophy in academia.

The Philosophy that implies, or signifies in geography is that subfield of broad philosophical ideas, which deals with metaphysical, epistemological and axiological issues in geography with geographic methodology in general and with more broadly related issues such as the perception and representation of space in place (Bortolotti, 2008). However, methodological issues concerning geographical knowledge have been debated for centuries. Richard Hartshorne is often created with its first primary systematic treatment in English the nature of geography. A critical assessment of current thought in the light of the past, which appeared in 1939 and promoted several volumes of critical essays in subsequent decades (Hartshorne, 1939).

Now, what is the object of metaphysics? Metaphysics deals with the existence or looking for the answers about what is real. Metaphysics is concerned about what is real and what 
does it mean to "be"? It seems that it is an abstract question. For example, metaphysis wonders what it means to be human. Metaphysics is extremely important in philosophy because it gives basic principles of our philosophical worldview. Metaphysics looks at what is real and the purpose and meaning of what is presented to students. It is "the study of the nature of ultimate reality" (Gutek, 2014, p. 5). It gives us the foundation of understanding about everything. Thus, it is known as the first philosophy. Aristotle initially divided metaphysics into three main sections and these remain the main branches of metaphysics:

- Ontology (the study of being and existence, including the definition, and classification of entities, physical or mental, the nature of their properties, and the nature of change);

- Natural theology (the study of God, including the nature of religion and the world, existence of the divine, questions about the creation, and the various other religious or spiritual issues); and

- Universal science (the study of first principles of logic and reasoning, such as the law of non-contradiction)

In doing so, it tries to integrate several spheres of discussion, which are typically separated. Geographers have usually seen fit to discuss ontology, epistemology, axiology, and methodology in isolation from the philosophy and object of the discipline (Harvey, 1969). A similar situation appeared in the geography scholars in Nepalese academia in the past. After the building of nation-state, the domestic geography made an outstanding achievement. Nevertheless, the philosophical research and high-level theoretical research in geography is consistently lagged within the academic circle. Thus, it seems that the intellectual poverty of geography appeared for a long time in the country. After 1990, few scholars attempted to strengthen the discussion, and innovation of geographical methods and philosophical and theoretical research in geography (Subedi, 2014), and some researchers have engaged in discussion of geographical methods and inevitable progress has been made (Koirala, 2008; 2010; Subedi, 2014; Sapkota, 2019).

Even though the application of philosophical assumptions on geographic research in Nepal is still generally holdups behind as a whole, examining the metaphysics in a broad sense and ontology in a specific sagacity, epistemology, and axiology of geography is still not taken seriously. Another serious problem is that some of the contemporary scholars in geography have a lack of interest to link the philosophical assumptions and research paradigms. It reflects the poor development of philosophical implications in geographic research in Nepal. It indicates the lack of ideas/knowledge about the vital significance of geographical philosophy in their research works (Foucault, 1972; 1979; 
1980). Therefore, this paper aims to explore the implications of vital philosophical assumptions and paradigms in geographic research.

Methodology and Ontology of Geography: Ontology is a branch of philosophy (metaphysics) that studies the nature of human beings' existence as individuals, in society, and the universe. Who are we? What are we here for? Ontology is a sub-branch of metaphysics, which deals with the study of being and existence or reality. In general terms, ontology is more specific than metaphysics. Ontology beliefs about reality; different kinds of research are initiated on various assumptions about what we believe truth or reality. Do we think that truth even exists? What is true? What we think reality is the well-shaped and what we believe we can know about reality. That is why it is vital to understand when we are learning about and commenting on the research.

Ormston, Spencer, Barnard, and Snape (2014) proclaim that ontology concerns the question of "whether or not there is a social reality that exists independently from human conceptions and interpretations and, closely related to this, whether there is a shared social reality or only multiple, context-specific ones" (p.4).

Science or knowledge and philosophical reasoning hold comparative perspectives that logical exploration requires philosophical direction or counsel, consideration, and a metaphysical foundation ((Foucault, 1972; 1979; 1980; Rosenberg, 2012). In this regard, Wittgenstein (1996) already underscored that the essential objective of philosophy is to explain thought logically and definite. Then, geographers discerned the importance of philosophical assumptions as part of their everyday lives or their academic discourses. For instance, Hill (1981) brought up that "all researches are guided by the philosophical belief, which impacts or initiates the selection of the research topic and method to complete the research with constant evolution. In short, the philosophical issues permeate into all aspects of the geographical research." Therefore, the geographical methodology is always a core content of geographical philosophy (Johnston, 1984).

Immanuel Kant examined the knowledge system and nature of geography very early and proposed the field of geography as "science about space." It was the philosophical ideas that formed the geographical methodology of the successive geographers Hettner and Hartshorne (see Holt-Jensen, 2006) to some extent. It was the beginning of systematic philosophical research into geography. Later on, the philosophy of geography maturing and influencing, a dispute between the methodologies of Hartshorne (1959) and Shaefer (1953) appeared, which initiated a quantitative revolution aimed at theorization. 
Due to several disagreements throughout the entire history of geography, which encouraged the contemporary scholars to advance of geographical ideas, philosophies, and improved geographical way of thinking (Liu, Tang, Liu, and Qin, 2017). Then, different scholars have discussed and examined the importance of philosophical understanding and its relationship with the methodology in geographic research. Schaefer (1953) hypothesized that "methodology properly deals with the position and scope of the field within the total system of the sciences and with the character and nature of its concepts." Johnston (1986) suggested that methodology is "a set of rules and procedures indicating how the research and argument go in the discipline," while Marinopoulou (2018) proposed that methodology is the conscientization of the method.

After realizing the importance of philosophies and methodologies in geographic research, scholars from the discipline started on the complete ontological framework. Geographers, like Harvey (1969), suggested, "Only to select a methodology with logical coherence cannot solve the geographical problems and more things or more appropriate geographical philosophies are required." He further argued that without proper or appropriate philosophical assumptions, it is almost impossible to make better methodological decisions in geographic research.

In Nepal, the geographical philosophy was discussing only the framework of epistemology and methodology, which entombed some scholars in a misinterpretation and misjudgment of geographical philosophy as epistemology and methodology in a narrow sense. Therefore, examining the ontology of geography is helpful for scholars to understand geographical philosophy fully, systematically develop it, and provide new dimensions and paths for the theoretical development of geography.

Regarding the ontological philosophical assumption possesses the question, geography scholars intend to answer. "What is the nature of being, reality, and existence? What can be known about it?" Both qualitative and quantitative research has differently addressed those issues because of their philosophical root or assumptions. Qualitative researchers tend to answer these questions by saying at their multiple realities are held by each person, and the truth or a reality is subjective.

Similarly, there is no access to reality independent of our minds. In practice, the qualitative researchers believe in using the words of participants in quotes and themes to show differing perspectives. Whereas quantitative researchers tend to answer the ontological question by saying that the reality is objective, that is, one reality, and reality can be described as independent of human perceptions. Thus, in practice, quantitative 
researchers show this by collecting complex data through surveys and observations and using numbers and statistics to show what is reality going on reality.

Methodology and Epistemology of Geography: Epistemology is the crucial philosophical standpoint of the study of knowledge; its nature, its requirements, and its limitation... what is knowledge, and how people know whether they know something ((Foucault, 1972; 1979; Bonjour, 2002). It is about the knowledge of reality, or it corresponds to the reality, which the researchers think. All research comes with the view of knowledge or what is knowable or worth knowing. Knowledge is the facts, information, and skills acquired through experience or education, the theoretical or practical understanding of a subject (Cohen, Manion, and Morrison, 2006). It could be said in more straightforward terms as to how knowledge and how knowledge is understood (Shotwell, 2014). Therefore, a branch of philosophy is about knowledge or learning. Knowledge is already out there, just waiting to be discovered (Foucault, 1972; $1979 ; 1980)$. Thus, it is our responsibility to uncover this universal, unchanging, and absolute truth.

The word epistemology comes from ancient Greek episteme, meaning to know. It is a decision and a debate leading to a decision about what is knowable and worth knowing, or it is a debate about what knowledge is. Therefore, epistemology is simply the "ology" of knowledge. It is any debate about what it is to know in your field. Therefore, philosophically speaking is the study of how we know things and whether things are true or false. Similarly, what steps do we need to take to gain knowledge of the world.

Epistemology senses the bridge between thinking and reality. It deals with what do we know? How do we know it? In addition, why is that knowledge meaningful? So, one big question that epistemology would consider is whether something is logical or not? Alternatively, can we prove using reasoning at a certain point? Therefore, it is imperative in the study of philosophy, which links with the research methodology. Thus, an epistemology or theory of knowledge is governed by two crucial elements in geographic research or philosophical standpoints, such as truth and belief. When we say we have the origin of knowledge, we know that what is the scope of that knowledge, the validity of the knowledge, the various sources from which we gather the knowledge we understand how and what is the ambit's of understanding this knowledge and that's what does epistemology.

There are three categories of knowledge discussed as follows: procedural knowledge, propositional knowledge, and personal knowledge. 
Procedural knowledge is about teaching students to do specific tasks, especially concerning hands-on learning, thus allowing the opinion for the students to retain propositional knowledge about those skills. Following on from procedural knowledge, propositional knowledge is the knowledge possessed by students on how to do certain things learned from the previous procedural knowledge phase. On the other hand, personal knowledge comes from previous personal experiences, which allows the individual to gain knowledge about a subject. They then can use this knowledge to assist them with procedural knowledge (Foucault, 1972; 1979).

Regarding the exploration of knowledge or reality, geography is organized into two related strands. Both are interrelated, and help to produce proper geographical reality or truth. However, geographical knowledge refers to the generalizations, principles, theories and models developed in geography, whereas geographical understanding is the ability to see the relationships between aspects of knowledge and construct an explanatory framework to illustrate these relationships (Couper, 2015; Sapkota, 2019). Likewise, geographical analysis and skills are a process by which students learn about and deepen their understanding of geographic knowledge.

Both explorations of reality or knowledge support the geography curriculum and teaching as well as research philosophically. The enhance of the geography curriculum, it helps to formulate a question, and research plan, recording and data representation skills, use a variety of spatial technologies, and communicate with appropriate geographical vocabulary. Similarly, students' passion for geographical learning should be stirred by a wide variety of activities for example, field trips, interpretation of remotely sensed images, application of GIS and GPS in the field data, use ethnographic methods, reading literary accounts of places, etc. to help them to figure out the geographical inquiry and investigation (Tang, 2010). Learning activities should also emphasize the ability to understand, explain, appreciate and use knowledge rather than simply reproduce it. The learning of skills should be made meaningful by using them to answer the questions or communicate information, which will help to connect the two strains of the curriculum as above stated (Kitchin and Tate, 2013).

Scholars involved in the philosophical discourse suggested that the epistemological approaches most flagrantly highlighted in meta-theoretical deliberations are those associated with positivism, critical realism, interpretivism, poststructuralism/ postmodernism, and pragmatism (e.g., Crotty, 1998; Tsoukas and Chia, 2011; Tsoukas and Knudsen, 2013). These philosophical viewpoints are based on a very idiosyncratic set of epistemological assumptions. 
Positivism advocates the set of philosophical ideas known as positivism that has long been associated with 'scientific' geography and has been a focus for much debate in the discipline (Couper, 2015). Comte's positivism and Vienna Circle's logical positivism provided the backdrop to the quantitative revolution in geography. It is the scientific, objective knowledge is based on observable, measurable facts, and claims that it can predict future events are its epistemological understanding (Donaldson, 1997; 2003). Whereas critical realism offers 'epistemological relativism,' meaning various types of data and methods are seen as acceptable, although critical realist often takes the form of a retrodictive, historical analysis (Reed, 2005; Bernstein, 1983). Proponents of critical realism also acknowledge that theories and knowledge never offer entirely specific knowledge and that 'social facts' are different from 'physical facts,' but that researchers should try to be as objective, and realistic as they can (Bhaskar, 1986; Fleetwood, 2005).

Interpretivism suggests that theories and concepts are inexorably too simplistic to represent the full lushness of the social world. Therefore, the greater the assortment of interpretations, stories and narratives as well as historical context factors that researchers can gather, the newer understandings (knowledge) they can create through their research (Isaeva, Bachmann, Bristow, Saunders, 2015; Crotty, 1998; Hatch and Yanow, 2003). Poststructuralism/postmodernism emphasizes and seeks to examine the role of dominant political ideologies in the constructing of what is generally known as 'truth,' 'knowledge,' and 'facts' (Habermas, 1967).

Therefore, knowledge is considered 'deconstructive,' enquiring and challenging conventional discourses (Chia 2003; Luhman \& Cunliffe 2013). Postmodernists aim to be radically reflexive and apply critical inspection to their role as researchers in coproducing the knowledge they study (Cunliffe, 2003). In contrast, pragmatism focuses on seeking, through various methods and their combination, helpful knowledge that enables successful action, providing solutions to problems, and informing future practice (Dewey, 1977; Elkjaer and Simpson, 2011). In this perspective, the social world is seen as a constant stream of action, of which the researcher is simply a part.

Regarding an epistemological assumption poses the question .... "What is truth? What is real knowledge? What is the relationship between the researcher and what is being studied?" How do we know what we claim to know? Can we acquire knowledge about reality? If we can, how do we succeed in inquiring about true, believes, knowledge about reality? 
Qualitative researchers tend to answer this question by saying that there is no one truth, but multiple truths or realities subjective to each person. Qualitative researchers want to gain knowledge of what participants think about the realities. So, in practice, researchers tried to lessen the distance between themselves and participants; they get into the field and participate with the participant wherever they are, whatever they are doing in life to gain an understanding of the participant's view on their realities. Whereas quantitative researchers tend to answer this question by saying that there is one truth or single reality because it is objective and can be studied. The relationship between participants and researchers is independent. Then, the truth can be studied without influencing or being influenced by participants. In practice, quantitative researchers show this belief by collecting data with or without having spent a lot of time with participants to understand what they think. They can collect data, analyze it, and gain actual knowledge or truth.

Methodology and Axiology of Geography: Axiology is a branch of philosophy that studies value. They ask questions about the values that guide our research begins. The word axiology is derived from a Greek word, where "Axios" means worth or value and "logos" means logic or theory, which deals with the quality or value (Rosenthal and Yudin, 1967). Jones and Brader-Araje (2005) defined that axiology as the branch of philosophy that studies judgments about values, including both ethics and aesthetics. Ethics examines the values in the realm of human conduct (Kneller, 1971). It deals with such questions as what is suitable for all men. How should one behave? What is right? What is morally wrong? What do we value? What value should guide or drive our research? Axiology can guide human life, individual, and social, secular or non-secular, in the right direction. Likewise, man searches for truth, praises beautiful, and attempts good. That is the philosophical standpoint of axiology serves as a guide for this purpose (Nigal, 1986). It talks about ethics and aesthetics as philosophical ideas in human and physical geography, respectively. Ethics is about behavior, which can act upon reality and also can influence or change reality. Ethics deals with the difference between right or wrong. This is the group of theoretical assumptions and arguments about what kinds of personal actions will maximize human forces and increase human happiness.

Similarly, it is the philosophy of values, which helps us decide to how and for what purpose these means should be utilized. Kneller (1971) argued about the importance and the implication of axiology in geographical studies and education. He says that values are everywhere in education (Cohen, Manion, and Morrison, 2006). In addition to that, he argues that society and educators evaluate each other based on their respective values, which they have embedded. Thus, axiology affects why you are learning (motivations, desire outcomes), what you are learning (dominant cultural practices), and even how you learn (factual recalls versus learning by doing). 
Axiological philosophical assumption poses the question ... What is the role of values? How should we behave? These are the basic questions of axiology deals by qualitatively or quantitatively in geographic research terms.

Qualitative researchers tend to answer this question by saying that reality is subjective and fact cannot be separated from values. Similarly, things cannot be described as they are, but only how we perceive them. So, there is no such thing as absolute objectivity, and values are entrenched in everything. So, the qualitative researchers show this belief by being upfront in reports about their values and biases. So that the readers can understand how the researcher is biased on their values and other specific things. On the other hand, quantitative researchers answer this question by saying that facts can be separated from values. They are showing it statistically that the research is valid and reliable something will learn about later and it's free of value and biases.

Paradigms of Geographic Research: Before to proceeding to address the philosophical issues, I consider as critical to take note that reporters do not have a reliable method of alluding to these paradigmatic methodologies. For instance, Tashakkori and Teddlie (1998) refer to paradigms of logical positivism, post-positivism, pragmatism, and constructivism, but Guba (1990) detaches positivism from the other three paradigms emerged as a challenge to it which are positivism, constructivism, and pragmatism. The point of this segment is to handle the ideas of epistemology and ontology, which support the three significant contending standards (positivism, constructivism, and pragmatism) and every one of them will be investigated and applied in the following sections.

Positivism: This worldview or paradigm deal with the truth or knowledge is objective and that it should be studied by the scientific method and through measuring it numerically and then analyzing it statistically and carries within the social research judgmental connotations. Due to its trustiness in the natural science model, many philosophers and social critics as inadequate in science (Irene, 2014) have considered it. Since the positivism's core has placed extreme stress on direct observations, it has been criticized for ignoring values, informed opinion, moral judgments, and beliefs (Habermas, 1972; 1974; Horkheimer, 1972; Kvernbekk, 2002; Shadish, 1995).

A philosophical perspective, based on realist ontology, proclaims that reality is driven by absolute natural laws. The role of science is to strive for casual relationships, an essential criterion for research, which resembles internal validity. Research then becomes objective, measurable, predictable, and controllable (Irene, 2014). As far as epistemology is concerned, it is rooted in an objectivist role and to use Guba's words in a 'dualist' position for the inquirer adopts a distant, no interactive posture, to his object of 
inquiry. Smith (1983) names this relationship of the knower and the known as a subjectobject relationship to the subject matter. He draws this distinction to highlight the valueneutrality of the positivist school of thought. Another issue of interest for positivists is generalizability. They contend that quantitative research is time and context-free. It is commonly asserted that the positivist approach to research is deductive in that it is tests and priori hypothesis or theory.

From a methodological point of view, positivism is inclined to the side of experimentation. Guba and Lincoln (1994) acknowledge this as they impose a top-down research approach. Since they place ontology at the top of the hierarchy and methodology at the bottom, it follows that the cause-effect ontological position of positivism constrains research at the methodological level to the use of empirical tests under carefully controlled conditions which Cook and Campell (1979) name as the experimental design.

Social-constructivism: Social constructionists acknowledge the influence of philosophers such as Immanuel Kant and Karl Marx (Galbin, 2014; Andrews, 2012). It is as we see that cannot be traced to a single source (Burr, 2003). The epistemology of social constructionism is that reality is socially constructed meaning that people make sense of the world based on social interactions. Therefore, the social constructivists believe that the goal of research is to understand participants' views, their socially constructed realities, and whatever is being studied. During the mid-1900s, philosophers explained it as a philosophy that looks how knowledge is created through social interactions (SavinBaden and Major, 2013). According to them social constructionism was prejudiced by several different people at different times and places (Galbin, 2014).

Therefore, social constructionist research focuses on how knowledge develops as a social construction (Savin-Baden and Major, 2013). It focuses on relationships and examines the individual's role in the construction of their realities or truths. Although social constructionists acknowledge the influence of genetics, they focus on the inspirations of socialization at both the individual and group levels (Galbin, 2014). In this manner, social constructivism underscores how meaning and understanding grow out of social encounters (Vygotsky, 1978). From the Vogotskian viewpoint, social interaction with the educator and different students is a massive aspect of the learning process. Knowledge is not exclusively developed inside the individual's psyche instead, connections inside a social content involve the student in sharing, constructing, and reproducing their thoughts/ideas and convictions (beliefs).

In expounding constructivists' thoughts, Arends (1998) states, that constructivism has confidence in the personal construction of meaning by the learner through experience. 
That importance is affected by the communication of earlier information and new occasions. Therefore, in an epistemological understanding, Galbin (2014) argues that "social constructionism involves challenging most of our common-sense knowledge of ourselves and the world we live in" (p. 83). Similarly, Burr (2003) highlights the fact that social constructionism heartens us to be thoughtful of how we perceive the world. The things we know about the world are largely based in large part on our social influences and observations (Irene, 2014). In academic discourse, generally, academicians use constructivism as a theory for teaching and learning. Because it is an approach to learning that holds that people actively construct or make their knowledge and that reality is determined by the learner's experiences" (Elliott, Kratochwill, Littlefield Cook, and Travers, 2000, p. 256).

The dawn of constructivism as an authentic paradigm for conducting qualitative research resulted as a reaction to quantitative methodologists' effort toward compromise of positivism and post-positivism. The most well-known qualitative researchers Guba and Lincoln (1994), plotted out a series of black and white contrasts between positivism and constructivism to stress their incompatibility. Ontologically speaking, there are multiple realities constructed by actors of research. Thus, they argue that research is grounded on a relativist ontology, which rejects the existence of any possible correct reality.

On an epistemological level, they reflect Smith's (1983) contention that the inquirer takes a subject-subject posture, whereas facts and values are inextricably linked. Hence, since the knower and the known are inseparable, research is value-bound. As almost all naturalists, they align to the belief that research is time, context-bound and that generalizations are not possible. As far as casual linkages are concerned, they contend that it is impossible with differentiate causes from effects.

A final principle on constructivism concerns the relationship between theory and research. As already noted, research-based on constructivism aligns with an emphasis with inductive logic employing from the particular to the general. From a methodological point of view, it proceeds hermeneutically by depicting individual construction as accurately as possible to compare and contrast it dialectically with the aim of reaching and generating a substantial consensus.

Pragmatism: The primary forms of pragmatism linked too closely with emerging American liberalism. They set too quickly in opposition to the European philosophies, including Marxism, that formed the radical edge of social inquiry for much of the 20th century (Wood and Smith, 2008). It was developed in America after the civil war and brought about intellectual and social changes up to the Second World War. However, 
in the last quarter-century, the philosophical landscape has changed: big gestures are being challenged by small acts, the persistence of structures has been unsettled by the flow of activity, new styles of agonistic democracy aim to remake rather than displace politics. For this and other reasons, pragmatism was marginalized even in philosophy and geography for many years. Pragmatism is not committed to any philosophy or way of thinking about reality or truth or knowledge. It is a philosophical perspective that is centrally concerned with the construction of meaning through experience. Pragmatists focus on the research questions or research problems at hand and use whatever research methods could be used to answer the question or solve that concern. Pragmatists are focused on practical outcomes of the research to solve the question or problem.

In other words, pragmatism is a philosophy, which asserts that meaning and knowledge can only be defined in terms of their role the experience. It emphasizes experiences, experimental inquiry, and truth as criteria for evaluating consequences. Pragmatism is the "position in philosophy that defines meaning and knowledge in terms of their function in experience, with reference to adjustment and the resolution of problematic situations" (Wood and Smith, 2008).

A pragmatist believes that the 'concrete' or 'particular' situation is essential in finding scientific knowledge and understanding the world. Accordingly, 'abstract' or 'general' laws and theories are also important and valuable as 'guiding principles' in any scientific inquiry (National Research Council, 2002). Therefore, pragmatist deals with theoretical concepts as well as practical situations in their research works. It is precisely what many geographers have been supporting, and that needs focus for the discipline. Pragmatism in geography prompted the improvement of applied geography. Specialists and thinkers concur that human perspectives, interests, desires, biases, and gathering esteems vary in time and space (Harney, McCurry, Scott, and Wills, 2016). Similarly, for the pragmatist geographers, spatial laws are substantial, and they give the framework for hypotheses formulation and data collection (Hitchcock and Hughes, 1995).

Here, man is in the centre as communicated by Vidal de La Blache and the French School of Geography (Sapkota, 2017). Thus, in humanistic geography, man, and science are accommodated. The chief point of current humanism in geology is the compromise of sociology and man, to oblige comprehension and insight, objectivity and subjectivity, and realism and vision. 


\section{Conclusion}

There are different philosophical assumptions and paradigms regarding truth, reality, knowledge value, writing styles, etc., in geographic research. Researchers should explore these to determine what they believe and how it could affect their research methods. This paper has discussed the philosophical routes, i.e., ontology, epistemology, and axiology as well as their implications in geographic research. The philosophical standpoints are closely connected with the research methodology, which is relatively weak in the geographic research in Nepal. The scholars are either neglected or not interested in entering into this type of philosophical debate in their research activities. This is a fundamental drawback of academic publications of geography in the country.

The paper contends is that the researcher's philosophical standpoint does determine research, but at the same time, research should reflect upon all possible theoretical and methodological stances. In the case of academic discourses and research activities, the entanglement of philosophical ideas to research methods becomes necessary. Research should be about investigating meaning and significance while at the same time being able to question, predict and control.

Overall, venues for future research regarding the use of critical discourse analysis that is based on the philosophical understanding may well be concerned with investigating literature related with the philosophy of all nations and societies in conflict. The existing literature on geographical research with positivism is then examined, and it is argued that there is a single reality, which can be measured and known. Therefore, they are more likely to use quantitative methods to measure the reality. Likewise, constructivist believe that there is no single reality or truth, and thus reality need to be interpreted, and therefore they are more likely to use qualitative methods to get those multiple realities.

Pragmatism has much broader relevance within both physical and human geography, not linked to particular research style. It believes that reality is constantly negotiated, debated, interpreted and therefore, the best method to use is to solve the problem or explores reality. Thus, the emancipatory character of the critical discourse ethics technique and methodology is likely to transform not only discriminatory assumptions and methodological biases of research, but also our biased notions of the 'other.'

\section{References}

Andrews, T. (2012). What is social constructionism? Grounded Theory Review, 11(1), pp. 39-46.

Arends, R. I. (1998). Resource handbook: Learning to teach. Boston: McGraw-Hill. 
Bernstein, R. (1983). Beyond objectivism and relativism. Philadelphia: University of Pennsylvania: University of Pennsylvania Press.

Bernstein, R.J. (1992) The resurgence of pragmatism. Social Research, 59(4), pp. 813-840. Bhaskar, R. (1986), Scientific realism and human emancipation. London: Verso.

Bonjour, L. (2002). Epistemology: Classic problems and contemporary responses. New York: Rowman \& Littlefield.

Bortolotti, L. (2008). An introduction to the philosophy of science. Cambridge: Polity Press.

Bryman, A. (1998). Quantity and quality in social research. London: Routledge.

Bryman, A. (2004) (2nd ed). Social research methods. Oxford: Oxford University Press.

Burr, V. (2003). What is social constructionism? Social Constructionism, pp. 1-27. New York, NY: Routledge.

Chia, R. (2003). Organization theory as a postmodern science. In H. Tsoukas and C. Knudsen (eds.), The Oxford handbook of organization theory: Meta-theoretical perspectives, pp. 113-40. Oxford: Oxford University Press.

Cohen, L., Manion, L. \& Morrison, K. (2006). Research methods in education. London: Routledge.

Cook, T. \& Campell, D. (1979). Quasi-experimentation: Design and analysis issues for field settings. Chicago: Rand McNally College Publishing Company.

Couper, P. (2015). A student's introduction to geographical thought: Theories, philosophies and methodologies. London: Sage.

Crotty, M. (1998). The Foundations of social research: Meaning and perspective in the research process. London: SAGE Publications Inc.

Cunliffe, A.L. (2003). Reflexive inquiry in organizational research: Questions and possibilities. Human Relations, 56 (8), pp. 983-1003.

Dewey, J. (1977). The bearings of pragmatism upon education. In J.A. Boydston (ed.), Middle works 4, pp. 178-191. Carbondale, IL: Southern Illinois University Press.

Donaldson, L. (1997). Derek Pugh: Scientific revolutionary in organization studies. In T. Clark (ed.), Advancement in organizational behaviour: Essays in honour of Derek S. Pugh, Aldershot: Ashgate.

Donaldson, L. (2003). Organization theory as a positive science. In H. Tsoukas and C. Knudsen (eds.), The Oxford handbook of organization theory: Meta-theoretical perspectives, pp. 39-62 Oxford: Oxford University Press.

Elkjaer, B. and Simpson, B. (2011). Pragmatism: A lived and living philosophy. What can it offer to contemporary organization theory? In H. Tsoukas and R. Chia (eds.), Philosophy and organization theory: Research in the sociology of organizations. Bradford: Emerald Publishing Ltd, 55-84.

Elliott, S.N., Kratochwill, T.R., Littlefield Cook, J. \& Travers, J. (2000). Educational psychology: Effective teaching, effective learning. Boston, MA: McGraw-Hill College. 
Fleetwood, S. (2005). Ontology in organization and management studies: A critical realist perspective. Organization, 12 (2), pp. 197-222.

Foucault, M. (1972). The archeology of knowledge. London: Tavistock Publications. Foucault, M. (1979). The history of sexuality, Volume I: An Introduction. London: Allen Lane.

Foucault, M. (1980). Power/knowledge: Selected interviews and other writings 19721977. Brighton: Harvester Wheatsheaf.

Galbin, A. (2014). An introduction to social constructionism. Social Research Reports, 26, pp. 82-92.

Goetz, J. \& LeCompte, M. (1984). Ethnography and qualitative design in educational research. Orlando, Fl: Academic Press.

Guba, E. \& Lincoln, Y. (1994). Competing paradigms in qualitative research. In N. Denzin and Lincoln (ed), Handbook of qualitative research (pp.105-177). Thousand Oaks, CA: Sage.

Guba, E.G. (1990). The paradigm dialogs. London: Sage.

Gutek, G. L. (2014). Philosophical, ideological, and theoretical perspectives on education. London: Pearson.

Habermas, J. (1967). On the logic of the social sciences. Cambridge, MA: MIT Press. Habermas, J. (1972). Knowledge and human interests. London: Heinemann.

Habermas, J. (1974). Theory and practice. London: Heinemann.

Harney, L., McCurry, J., Scott, J., \& Wills, J. (2016). Developing 'process pragmatism to underpin engaged research in human geography. Progress in Human Geography, pp. 1-18. DOI: $10.1177 / 0309132515623367$.

Hartshorne, R. (1959). Prospective on the nature of geography. Rand McNally, Chicago, IL.

Harvey, D. (1969). Explanation in geography. London: Edward Arnold.

Hatch, M.J. \& Yanow, D. (2003). Organization theory as an interpretive science. In H. Tsoukas and C. Knudsen (eds.), The Oxford handbook of organization theory: Meta theoretical perspectives, pp. 63-87. Oxford: Oxford University Press.

Hitchcock, G. \& Hughes, D. (1995). Research and the teacher. London: Routledge. Holt-Jenson, A. (2006). Geography: History and concept-A students' guide. London: Sage. Horkheimer, M. (1972). Critical theory: Selected essays. New York: Herder \& Herder. Irene, D. (2014). The ontological and epistemological foundations of qualitative and quantitative approaches to research with particular reference to content and discourse analysis of textbooks. International Journal of Economics, Commerce and Management, II (10), pp. 1-17.

Isaeva, N., Bachmann, R., Bristow, A., \& Saunders, M.N.K. (2015). Why the epistemologies of trust researchers matter. Journal of Trust Research, 5 (2) pp. 153-169.

James, W. (2000). Pragmatism and other writings. London: Penguin. 
Johnston, R. J. (1984). Philosophy and human geography: An introduction to contemporary approaches. London: Edward Arnold.

Johnston, R. J. (1986). On human geography. Oxford: Basil Blackwell.

Jones, M.G. and Brader-Araje,L.(2005). The impact of constructivism on education: Language, discourse, and meaning. American Communication Journal, 5 (3) pp. 1-10.

Kitchin, R. \& Tate, N. (2013). Conducting research in human geography: Theory, methodology and practice. England: Routledge.

Kneller, G. F. (1971). Introduction to the philosophy of education. USA: John Wiley \& Sons, Inc.

Koirala, H. L. (2008). Geography in crisis: Is geography in Nepal an exception? The Geographical Journal of Nepal, Vol. pp. 6, 31-44.

Koirala, H. L. (2010). Are geographer's research methodologies really poor? Tribhuvan University Journal, 27, pp. 61-70.

Kvernbekk, T. (2002). Perspectives in philosophy of science. In T. Lund (ed), Introduction to research methodology, p.19-78. Norway: Unipub forlag.

Liu, K., Tang, M., Liu, R. and Qin, R (2017). Geography's “world view": The ontological issues of geography. J. Geogr. Sci. 27, 1541-1555 (2017). ). https:// doi.org/10.1007/ s11442-017-1451-z

Luhman, J.T. and Cunliffe, A. L. (2013). Key concepts in organization theory. London: Sage.

Marinopoulou A. (2018) Critical theory: Epistemological content and method. In: Liamputtong P. (eds) Handbook of research methods in health social sciences. Springer, Singapore. https://doi.org/10.1007/978-981-10-2779-6_58-1

National Research Council (2002). Scientific research in education. Washington, DC: The National Academies Press. https://doi.org/10.17226/10236

Nigal, S.G. (1986). Axiological approaches to Vedas. New Delhi: Northern Book Centre.

Ormston, R., Spencer, L., Barnard, M., \& Snape, D. (2014). The foundations of qualitative research. In J. Ritchie, J. Lewis, C. Nicholls and R. Ormston (eds.), Qualitative Research Practice: A guide for social science students and researchers, pp. 1-25. Los Angeles: Sage.

Patton, M.Q. (1990). Qualitative evaluation and research methods. Newbury Park, CA: Sage Publications, Inc.

Reed, M. (2005). 'Reflections on the 'realist turn' in organization and management studies', Journal of Management Studies, 42 (8), pp. 1621-44.

Relph, E. (1981). Rational landscapes and humanistic geography. Totowa (NJ): Croom Helm. Rosenberg, A. (2015). Philosophy of social science. London: Westview Press.

Rosenthal, M. \& Yudin, P. (1967). A dictionary of philosophy. Moscow: Progress Publishers.

Sapkota, K. (2017). Fundamentals of geographical thought. Kathmandu: Mahila Ojshwi Manch. 
|| 100 || The Third Pole: Journal of Geography, Volume 20 - 21, 2021

Sapkota, K. (2019). Academic discourse on the dualism between regional geography and systematic geography. The Third Pole: Journal of Geography, 18-19, pp. 111-122.

Savin-Baden, M. \& Howell Major, C. (2013). Qualitative Research: The essential guide to theory and practice. New York, NY: Routledge.

Schaefer, F. (1953). Exceptionalism in geography. Annals of the Association of American Geographers, 43, pp. 226-49.

Shadish, W. (1995). Philosophy of science and the quantitative-qualitative debates. Evaluation and Program Planning, 18(1), pp. 63-75.

Shotwell, A. (2014). Implicit knowledge: How it is understood and used in feminist theory. Philosophy Compass, 9/5, pp. 315-324, Doi 10.1111/phc3.12130

Smith, J. (1983). Quantitative versus qualitative research: An attempt to clarify the issue. Educational Researcher, 12(3), pp. 6-13.

Subedi, B.P. (2014). The state of geography teaching and research in Nepal: A review and reflection. Kathmandu: Martin Chautari.

Suchet-Pearson, S., Wright, S., Lloyd, K. \& Burarrwanga, L. (2013). Caring as country: Towards an ontology of co-becoming in natural resource management. Asia Pacific Viewpoint, 52 (2), pp. 185-97.

Tang, M. (2010). The methodological issues of human geography research in mainland of China. Human Geography, 25 (4), pp. 1-6.

Tashakkori, A. \& Teddlie, C. (1998). Introduction to mixed method and mixed model studies in the social and behavioral sciences. USA: Sage.

Tsoukas, H \& C. Knudsen (eds.) (2003). The Oxford handbook of organization theory: Meta-theoretical perspectives. Oxford: Oxford University Press.

Tsoukas, H. \& Knudsen, C. (2003). Introduction: The need for meta-theoretical reflection in organization theory. In $\mathrm{H}$. Tsoukas and C. Knudsen (eds.), The Oxford handbook of organization theory: Meta-theoretical perspectives. Oxford: Oxford University Press.

Tsoukas, H. \& R. Chia (eds.) (2011), Philosophy and organization theory. Research in the sociology of organizations, 32. Bradford: Emerald.

Vygotsky, L. S. (1978). Mind in society: The development of higher psychological processes. Cambridge, MA: Harvard University Press.

Wittgensteins, L. (1996). Philosophy of education. London: Edward Arnold.

Wood, N. \& Smith, S.J. (2008). Pragmatism and geography. Geoforum, 39 (4), pp. 1527-29. DOI: 10.1016/j.geoforum.2008.06.003. 